SUMMARY OF THE NATIONAL ATMOSPHERIC DEPOSITION PROGRAM/NATIONAL

TRENDS NETWORK INTERSITE-COMPARISON PROGRAM,

NOVEMBER 1978-NOVEMBER 1989

By John D. Gordon, Timothy C. Willoughby, and LeRoy J. Schroder

U.S. GEOLOGICAL SURVEY

Water-Resources Investigations Report 91-4061

Denver, Colorado 1991 
U.S. DEPARTMENT OF THE INTERIOR

MANUEL LUJAN, JR., Secretary

U.S. GEOLOGICAL SURVEY

Dallas L. Peck, Director

For additional information write to:

Chief, Branch of Quality Assurance U.S. Geological Survey Box 25046, Mail Stop 401 Federal Center

Denver, C0 80225-0046
Copies of this report can be purchased from:

U.S. Geological Survey Books and Open-File Reports Section Box 25425, Mail Stop 517

Federal Center

Denver, C0 80225-0425 
Page

Abstract--

Introduction-1.

Purpose and scope-1 3

History-n 3

Results of intersite-comparison studies-- 6

Evaluation of $\mathrm{pH}$ determinations using network operations
subcommittee measurement-accuracy criteria-

$\mathrm{pH}$ determinations outside measurement-accuracy criteria---- 11

Success rates for achieving $\mathrm{pH}$ measurement-accuracy criteria--- 12

Differences between measured and median pH- 12

Evaluation of specific-conductance determinations using Network

Operations Subcommittee measurement-accuracy criteria-

Specific-conductance determinations outside measurementaccuracy criteria-...

Success rates for achieving specific-conductance measurementaccuracy criteria-n 18

Differences between measured and median specific conductance--- 19

Evaluation of Network Operations Subcommittee measurement-accuracy

criteria-1.

Summary-1-0

Selected references-1

\section{FIGURES}

Figure 1. Chart showing the history of the intersite-comparison study program-

2-10. Graphs showing:

2. Relation between site operators meeting measurementaccuracy criteria for $\mathrm{pH}$ determinations, in percent, and intersite-comparison study number.....

3. Frequency distribution of measurement error for $\mathrm{pH}$ determinations that failed to meet the measurementaccuracy criteria in studies 1-24-.

4. Frequency distribution of differences between measured and median $\mathrm{pH}$ for studies 1-24-1

5. $A$, Interquartile range of measured minus median $\mathrm{pH}$ for each intersite-comparison study; $B$, Median $\mathrm{pH}$ for each intersite-comparison study-...

6. Comparison of site operators meeting measurement-accuracy criteria for specific-conductance determinations and

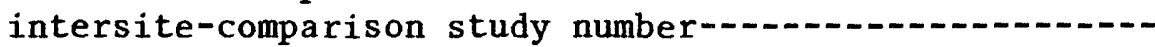

7. Frequency distribution of differences between measured and median specific conductance for studies 1-24--.---

8. A, Interquartile range of measured minus median specific conductance for each intersite-comparison study; $B$, Median specific conductance for each intersitecomparison study- 
Figures 2-10. Graphs showing--Continued:

9. A, Relation between site operators meeting $\mathrm{pH}$ measurement-accuracy criteria, in percent, and the median $\mathrm{pH}$ of the intersite-comparison study reference solutions used in studies 1-10;

$B$, Relation between site operators meeting $\mathrm{pH}$ measurement-accuracy criteria, in percent, and the median $\mathrm{pH}$ of the intersite-comparison study reference solutions used in studies 11-24, excluding study 22-...-

10. Relation between site operators meeting specificconductance measurement-accuracy criteria, in percent, and the median specific conductance of the intersite-comparison study reference solutions-----

TABLES

Table 1. Maximum and minimum reported values and percentiles for $\mathrm{pH}$ results obtained from intersite-comparison studies----.--

2. Maximum and minimum reported values and percentiles for specific-conductance results obtained from intersitecomparison studies-..-

3. Summary statistics obtained from analysis of site-operator results for $\mathrm{pH}$ measurements obtained from intersitecomparison studies-.-.

4. Summary statistics obtained from analysis of site-operator results for specific-conductance measurements obtained from intersite-comparison studies--

CONVERSION FACTORS AND ABBREVIATED WATER QUALITY TERMS

Multiply

liter (L) milliliter $(\mathrm{mL})$
By

1.0567

0.03381
To obtain

quart, liquid ounce, fluid

The following terms and abbreviations also are used in this report:

microsiemens per centimeter at 25 degrees Celsius $(\mu \mathrm{S} / \mathrm{cm})$ megohm $(M \Omega)$ 


\title{
SUMMARY OF THE NATIONAL ATMOSPHERIC DEPOSITION PROGRAM/NATIONAL TRENDS NETWORK INTERSITE-COMPARISON PROGRAM, NOVEMBER 1978-NOVEMBER 1989
}

\author{
By John D. Gordon, Timothy C. Willoughby, \\ and LeRoy J. Schroder
}

\begin{abstract}
Intersite-comparison studies have been used since November 1978 to assess the accuracy and precision of $\mathrm{pH}$ and specific-conductance measurements made by National Atmospheric Deposition Program and National Trends Network site operators. Between November 1978 and June 1980, the first four intersitecomparison studies were administered by the Illinois State Water Survey Central Analytical Laboratory, Champaign, Illinois. The U.S. Geological Survey assumed responsibility for the program in October 1981. Twenty-four intersite-comparison studies were completed as of November 1989 . The $\mathrm{pH}$ and specific-conductance measurements made during intersite-comparison studies were primarily evaluated using two methods of analysis. The first method of analysis evaluated site-operator reported values in terms of the measurementaccuracy criteria established by the Network Operations Subcommittee. The measurement-accuracy criteria for $\mathrm{pH}$ are \pm 0.10 unit if the most probable $\mathrm{pH}$ value is 5.0 or less or \pm 0.30 unit if the most probable $\mathrm{pH}$ value exceeds 5.0 . In every intersite-comparison study except study 22 , the median $\mathrm{pH}$ was less than 5.0. The measurement-accuracy criteria for specific conductance are \pm 4.0 microsiemens per centimeter of the most probable value. The second method of analysis evaluated the differences between site-operator reported values and network median values.
\end{abstract}

The percentage of site operators reporting $\mathrm{pH}$ values within the measurement-accuracy criteria established by the Network Operations Subcommittee increased from an average of 61 percent for intersite-comparison studies 1 through 10 to an average of 78 percent for studies 11 through 24 . The operators of 12 percent of the sites that participated in studies 1 through 24 accounted for 29 percent of the $\mathrm{pH}$ determinations that failed to meet the measurement-accuracy criteria.

Excluding study 22 because of the different $\mathrm{pH}$ measurement-accuracy criteria that were applied, a nonparametric correlation analysis indicated a statistically significant association between the median $\mathrm{pH}$ of the reference solution and the percentage of site operators reporting $\mathrm{pH}$ values that met the Network Operations Subcommittee measurement-accuracy criteria in studies 11 through $24(\alpha=0.05, r=-0.71)$. No statistically significant correlation between the median $\mathrm{pH}$ of the reference solution and the percentage of site operators reporting $\mathrm{pH}$ values that met the measurement-accuracy criteria was determined for studies 1 through 10 . 
The percentage of site operators reporting specific-conductance values within the measurement-accuracy criteria varied from 88 to 97 percent when the median specific conductance of the reference solution was less than 25 microsiemens per centimeter at 25 degrees Celsius. When the median specificconductance value of the reference solution was between 30 and 60 microsiemens per centimeter at 25 degrees Celsius, 38 to 82 percent of the site operators reported values that met the measurement-accuracy criteria.

A nonparametric correlation analysis indicated a statistically significant association between the median specific conductance of the reference solution and the percentage of site operators reporting specific-conductance values that met the measurement-accuracy criteria in studies 1 through 24 $(\alpha=0.05, r=-0.82)$.

\section{INTRODUCTION}

The Association of State Agricultural Experiment Stations established the National Atmospheric Deposition Program (NADP) in 1978 to study atmospheric deposition and its effects (Galloway and others, 1978). In 1980, Congress passed the Acid Precipitation Act (Public Law 96-294) authorizing the creation of a National Acid Precipitation Assessment Program (NAPAP). The National Trends Network (NTN) was established in 1980 by a NAPAP interagency task force (Schroder and Malo, 1984). The NADP and NTN share common operational procedures and site-location criteria. The NADP and NTN also use the same analytical laboratory to assess wet-deposition sample chemistry. Since 1982, a Network Operations Subcommittee (NOS) has coordinated the operation of both the NADP and the NTN. Data from the NADP and NTN are compiled in common computer files using the joint designation NADP/NTN. Authors of reports published previously describe the background of the NADP/NTN in further detail (Lindberg and others, 1982; See and others, 1988).

Monitoring the acidity of wet deposition is a major objective of the NADP/NTN. Because physical and chemical reactions may cause the $\mathrm{pH}$ of a wet-deposition sample to change over time (Hem, 1985), the weekly onsite measurements of $\mathrm{pH}$ are potentially the best measurements of the acidity of the wet-deposition samples collected by the NADP/NTN. Analys is of data collected in the Electric Power Research Institute Sulfate Regional Experiment determined that differences between onsite and laboratory measurements of sample $\mathrm{pH}$ are frequently statistically significant (Topol and Schwall, 1987).

The intersite-comparison program is an ongoing, external qualityassurance program that has been operated for the NADP/NTN by the U.S. Geological Survey since 1981. The Central Analytical Laboratory (CAL) in Champaign, I1l. initiated the intersite-comparison program to assess the ability of NADP/NTN site operators to make accurate and precise $\mathrm{pH}$ and specific-conductance measurements. The accuracy of a measurement refers to the extent to which it agrees with the accepted value for that quantity, whereas precision is the degree of similarity among independent measurements of the same quantity, without reference to the known or true value (V.R. Schneider, U.S. Geological Survey, written commun., 1990). Site operators are required to make onsite measurements of $\mathrm{pH}$ and specific conductance each week in conjunction with the collection of wet-deposition samples that have a volume of $50 \mathrm{~mL}$ or greater. Site-operator performance in the intersitecomparison program is the primary indicator of the quality of these field 
analyses. Weekly measurements of a $4.30 \mathrm{pH}$ check solution and performance during site audits are additional indicators of measurement quality.

During each intersite-comparison study, reference samples were distributed to all site operators with instructions that they measure the $\mathrm{pH}$ and specific conductance using standard NADP/NTN procedures. The reference samples were distributed as single blind samples (that is, they were known to be reference samples, but the $\mathrm{pH}$ and specific conductance were not known to the site operator). Reference solutions for the intersite-comparison studies typically consisted of aliquots of homogeneous dilute nitric-acid solutions with target $\mathrm{pH}$ and specific-conductance values within the normal range for wet deposition. The reference solutions were usually prepared by adding a small amount (less than $0.50 \mathrm{~mL}$ ) of concentrated nitric acid to ultrapure-deionized water (greater than $16.7 \mathrm{M} \Omega$ ) in a 50-liter polyethylene carboy. The exact amount of concentrated nitric acid depended upon the selected target $\mathrm{pH}$ and the volume of solution prepared. The preparation of reference solutions is discussed in detail in a previous report (See and others, 1990b).

\section{Purpose and Scope}

Intersite-comparison studies have been used since November 1978 to assess the accuracy and precision of $\mathrm{pH}$ and specific-conductance measurements made by NADP/NTN site operators. A total of 24 intersite-comparison studies was completed as of November 1989. This report summarizes the results of the first 24 studies and evaluates the measurement-accuracy criteria. The $\mathrm{pH}$ and specific-conductance measurements made during intersite-comparison studies were primarily evaluated using two methods of analysis. The first method of analysis evaluated site-operator reported values in terms of the measurementaccuracy criteria established by the Network Operations Subcommittee. The second method of analysis evaluated the differences between site-operator reported values and network median values.

\section{History}

Because of cost constraints, laboratory-certified values for $\mathrm{pH}$ and specific conductance were not obtained for the reference samples used in the intersite-comparison program. In place of certified values, the mean $\mathrm{pH}$ and specific conductance for all responding site operators originally were used as the most probable values.

In response to growing concern among members of the NOS that outlying values were affecting the mean values for $\mathrm{pH}$ and specific conductance, Brooks and others (1988) confirmed that outliers in the data set significantly affected the mean values in some studies. Beginning with study 16 , the median $\mathrm{pH}$ and median specific-conductance values for all responding site operators have been used as the most probable values, and the F-pseudosigma has been used to measure the spread of the data. Experience has shown that the median value of about 200 analyses by the site operators is a better estimate of the most probable value than either the limited number of in-house laboratory analyses that are performed or the theoretical target value (See and others, 1990a). For consistency, the data analysis for this report uses the median $\mathrm{pH}$ and specific-conductance values as the most probable values for all 24 intersite-comparison studies. 
During the 11 years between the completion of intersite-comparison study 1 and study 24, the operating protocol of the intersite-comparison program was revised repeatedly (fig. 1). The first four intersite-comparison studies were administered by the CAL between November 1978 and June 1980 . The U.S. Geological Survey assumed responsibility for the program in October 1981. Additional changes in the operating protocol included the initiation of semiannual site-operator training classes, the decision by the NOS to provide site operators with $\mathrm{pH}$ electrodes, and the creation of a site-visitation program.

During studies 5-21, all site operators were asked to return the remaining part of the study reference solution for possible re-analysis by the U.S. Geological Survey. In studies 5-15, re-analysis was done when (1) reported $\mathrm{pH}$ values were not within "re-analysis limits" established by the U.S. Geological Survey of the mean of all site operator values $\pm 0.4 \mathrm{pH}$ unit; or (2) reported specific-conductance values differed by more than 20 percent from the mean of all specific conductance values reported by site operators. The "re-analysis limits" were established by the U.S. Geological Survey to select samples for re-analysis only if the site operator failed to meet the measurement-accuracy criteria and reported an outlying value. Re-analysis determined if the sample had been contaminated or undergone a change in chemistry. Re-analysis also helped to determine if the erroneous measurement was because of site-operator error or an equipment malfunction (See and others, 1990a).

In studies 16-21, nonparametric statistics were used as the basis for sample re-analysis. Samples were re-analyzed when the reported values exceeded a new "re-analysis limit" established by the U.S. Geological Survey of the median \pm 1.5 times the $F$-pseudosigma value calculated from all responding site operators. The F-pseudosigma is a nonparametric statistic analogous to the standard deviation. Because the F-pseudosigma is calculated using the 25 th and 75 th percentiles in a data set, it is resistant to the effect of extreme outliers (Hoaglin and others, 1983). More than 99 percent of the re-analyses by the U.S. Geological Survey of $\mathrm{pH}$ and specific-conductance samples were within the measurement-accuracy sriteria established by the NOS. These results confirmed that sample contamination prior to shipment to the site operator or sample deterioration during shipment and storage were extremely rare explanations for a site operator to fail to achieve the measurement-accuracy criteria. For this reason, the practice of requesting that the remaining parts of intersite-comparison solutions be returned to the U.S. Geological Survey for re-analyses was discontinued. Beginning with study 22 , only those site operators reporting a value or values outside the measurement-accuracy criteria or the 1.5 times F-pseudosigma range that they believed to be valid were encouraged to return the remaining part of the reference solution to the U.S. Geological Survey for re-analysis. Authors of the 1988 external quality-assurance summary report discuss re-analyses of reference solutions in further detail (See and others, 1990a). 
November 1978

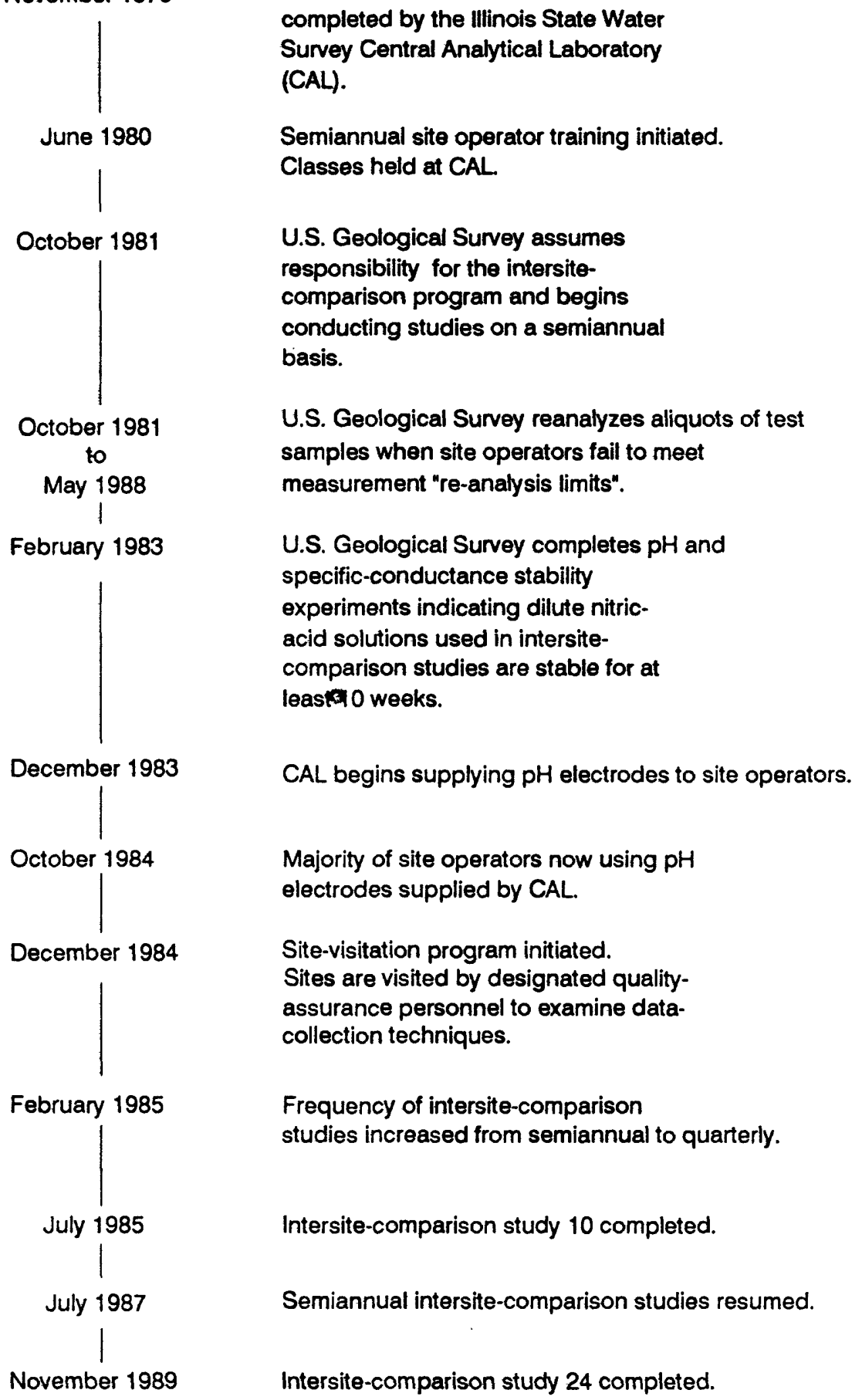

November 1989

\section{U.S. Geological Survey assumes} responsibility for the intersitecomparison program and begins conducting studies on a semiannual basis.

U.S. Geological Survey reanalyzes aliquots of test samples when site operators fail to meet measurement "re-analysis limits".

U.S. Geological Survey completes $\mathrm{pH}$ and specific-conductance stability experiments indicating dilute nitricacid solutions used in intersitecomparison studies are stable for at leasta 0 weeks.

CAL begins supplying pH electrodes to site operators.

Majority of site operators now using $\mathrm{pH}$ electrodes supplied by CAL.

Site-visitation program initiated.

Sites are visited by designated qualityassurance personnel to examine datacollection techniques.

Frequency of intersite-comparison studies increased from semiannual to quarterly.

Intersite-comparison study 10 completed.

Semiannual intersite-comparison studies resumed.

Intersite-comparison study 24 completed.

Figure 1. History of the intersite-comparison study program. 


\section{RESULTS OF INTERSITE-COMPARISON STUDIES}

During each study, about 3 percent of the site operators reported that their $\mathrm{pH}$ or specific-conductance equipment was inoperable. About 1 to 2 percent of the site operators typically reported their results after the scheduled closing date of each study. Non-responding site operators (that is, operators that did not return results or an explanation that their equipment was inoperable) constituted another 4 to 7 percent of the site operators in most studies. Only data that were submitted by the closing date for each study were evaluated in this report. The maximum and minimum reported values, median (the 50 th percentile), quartiles (the 25 th and 75 th percentiles) and other percentiles for $\mathrm{pH}$ and specific-conductance results in intersitecomparison studies $1-24$ are listed in tables 1 and 2 . Percentile rankings provide one indication of distribution shape and can be used to assess the degree of similarity among independent values (Hoaglin and others, 1983).

\section{Evaluation of $\mathrm{pH}$ Determinations Using Network Operations} Subcommittee Measurement-Accuracy Criteria

The NOS measurement-accuracy criteria for $\mathrm{pH}$ determinations are $\pm 0.10 \mathrm{pH}$ unit of the most probable value if the $\mathrm{pH}$ of the reference solution is 5.0 or less. When the most probable $\mathrm{pH}$ value of the reference solution exceeds 5.0 , the accuracy criteria increase to $\pm 0.30 \mathrm{pH}$ unit. In every intersitecomparison study except study 22 , the median $\mathrm{pH}$ was less than 5.0 (table 1).

During intersite-comparison studies $1-24,3,124 \mathrm{pH}$ determinations were done. The NOS measurement-accuracy criteria were met for 2,319 of these $\mathrm{pH}$ determinations ( 74 percent). Table 3 depicts the percentage of site operators that met the measurement-accuracy criteria for $\mathrm{pH}$, the number of site operators responding, and the F-pseudosigma for each intersite-comparison study. The F-pseudosigma provides a measure of the degree of similarity among the independent determinations made in each study. Relatively smaller F-pseudosigma values are indicative of less spread in the reported values.

Because of significant changes in the operating protocol of the network, it is meaningful to compare the results of studies 1-10 with the results of studies 11-24. Beginning with study 11, most of the site operators were using electrodes supplied by CAL. Additional changes designed to improve the quality of the field measurements also went into effect immediately prior to study 11 , including semi-annual site operator training classes and a sitevisitation program. The percentage of site operators reporting $\mathrm{pH}$ values within the measurement-accuracy criteria increased from an average of 61 percent for intersite-comparison studies 1-10 to an average of 78 percent for studies 11-24. Although a definitive relation cannot be established, it can be inferred that supplying site operators with uniform-quality $\mathrm{pH}$ electrodes, providing instruction at training classes, and initiating a site-visitation program positively affected the results of $\mathrm{pH}$ determinations in the intersitecomparison program. 
Table 1.--Maximum and minimum reported values and percentiles for $\mathrm{pH}$ results obtained from intersite-comparison studies

[pH, in units]

\begin{tabular}{|c|c|c|c|c|c|c|c|c|c|}
\hline \multirow{2}{*}{$\begin{array}{c}\text { Intersite- } \\
\text { comparison } \\
\text { study } \\
\text { number }\end{array}$} & \multirow{2}{*}{\multicolumn{2}{|c|}{$\begin{array}{c}\text { Date of } \\
\text { study }\end{array}$}} & \multirow{2}{*}{$\begin{array}{c}\text { Mini- } \\
\text { mum }\end{array}$} & \multicolumn{5}{|c|}{ Percentile } & \multirow{2}{*}{$\underset{\text { mum }}{\operatorname{Maxi-}}$} \\
\hline & & & & $\overline{10 t h}$ & 25 th & 50 th & $75 \mathrm{th}$ & 90 th & \\
\hline 1 & November & 1978 & 2.63 & 2.63 & 2.70 & 3.02 & 3.05 & 3.43 & 3.43 \\
\hline 2 & August & 1979 & 3.30 & 3.62 & 3.95 & 4.08 & 4.28 & 4.67 & 8.81 \\
\hline 3 & November & 1979 & 3.60 & 4.11 & 4.26 & 4.47 & 4.60 & 5.19 & 5.95 \\
\hline 4 & June & 1980 & 3.50 & 3.98 & 4.22 & 4.29 & 4.32 & 4.58 & 7.20 \\
\hline 5 & October & 1981 & 3.30 & 3.99 & 4.19 & 4.29 & 4.36 & 4.50 & 5.42 \\
\hline 6 & April & 1982 & 3.73 & 4.28 & 4.44 & 4.57 & 4.62 & 4.73 & 6.35 \\
\hline 7 & November & 1982 & 3.32 & 3.87 & 3.95 & 4.03 & 4.09 & 4.19 & 4.88 \\
\hline 8 & May & 1983 & 3.00 & 3.55 & 3.76 & 3.84 & 3.89 & 4.00 & 4.40 \\
\hline 9 & November & 1983 & 3.45 & 4.38 & 4.52 & 4.61 & 4.67 & 4.79 & 5.97 \\
\hline 10 & July & 1984 & .38 & 3.95 & 4.08 & 4.12 & 4.18 & 4.27 & 7.50 \\
\hline 11 & February & 1985 & 3.97 & 4.37 & 4.46 & 4.55 & 4.60 & 4.71 & 6.60 \\
\hline 12 & May & 1985 & 3.39 & 3.93 & 4.08 & 4.13 & 4.18 & 4.25 & 6.30 \\
\hline 13 & August & 1985 & 3.61 & 4.59 & 4.71 & 4.79 & 4.86 & 4.99 & 7.50 \\
\hline 14 & November & 1985 & 3.65 & 4.47 & 4.55 & 4.61 & 4.67 & 4.74 & 8.10 \\
\hline 15 & February & 1986 & 3.33 & 4.48 & 4.57 & 4.60 & 4.66 & 4.73 & 7.25 \\
\hline 16 & May & 1986 & 3.87 & 4.82 & 4.89 & 4.96 & 5.02 & 5.09 & 5.90 \\
\hline 17 & August & 1986 & 3.29 & 3.81 & 3.89 & 3.92 & 3.95 & 4.00 & 5.91 \\
\hline 18 & November & 1986 & 3.64 & 4.24 & 4.29 & 4.32 & 4.35 & 4.40 & 5.60 \\
\hline 19 & July & 1987 & 3.71 & 4.35 & 4.45 & 4.50 & 4.54 & 4.58 & 5.04 \\
\hline 20 & October & 1987 & 3.65 & 4.56 & 4.67 & 4.73 & 4.79 & 4.85 & 6.52 \\
\hline 21 & May & 1988 & 3.70 & 4.34 & 4.38 & 4.40 & 4.44 & 4.48 & 13.0 \\
\hline 22 & November & 1988 & 3.47 & 4.90 & 4.98 & 5.06 & 5.13 & 5.19 & 5.50 \\
\hline 23 & May & 1989 & 3.42 & 4.55 & 4.61 & 4.68 & 4.72 & 4.76 & 5.40 \\
\hline 24 & November & 1989 & 3.70 & 3.94 & 3.98 & 4.01 & 4.04 & 4.08 & 6.10 \\
\hline
\end{tabular}


Table 2.--Maximum and minimum reported values and percentiles for specificconductance results obtained from intersite-comparison studies

[specific conductance, in microsiemens per centimeter at 25 degrees Celsius]

\begin{tabular}{|c|c|c|c|c|c|c|c|c|c|}
\hline \multirow{2}{*}{$\begin{array}{c}\text { Intersite- } \\
\text { comparison } \\
\text { study } \\
\text { number }\end{array}$} & \multirow{2}{*}{\multicolumn{2}{|c|}{$\begin{array}{c}\text { Date of } \\
\text { study }\end{array}$}} & \multirow{2}{*}{$\begin{array}{c}\text { Mini- } \\
\text { mum }\end{array}$} & \multicolumn{5}{|c|}{ Percentile } & \multirow{2}{*}{$\begin{array}{c}\text { Maxi- } \\
\text { mum }\end{array}$} \\
\hline & & & & $10 \mathrm{th}$ & 25 th & $50 \mathrm{th}$ & $75 \mathrm{th}$ & $90 \mathrm{th}$ & \\
\hline 1 & November & 1978 & 0.30 & 0.30 & 93.40 & 192 & 420 & 422 & 422 \\
\hline 2 & August & 1979 & 26.0 & 29.0 & 31.6 & 35.1 & 37.6 & 40.9 & 42.6 \\
\hline 3 & November & 1979 & .31 & 30.9 & 36.8 & 39.6 & 40.8 & 44.5 & 68.8 \\
\hline 4 & June & 1980 & 10.0 & 19.7 & 20.9 & 22.3 & 24.1 & 25.3 & 42.3 \\
\hline 5 & October & 1981 & .30 & 18.2 & 19.3 & 21.6 & 23.1 & 24.8 & 63.5 \\
\hline 6 & April & 1982 & .12 & 10.0 & 11.2 & 12.4 & 13.2 & 13.9 & 94.8 \\
\hline 7 & November & 1982 & 3.20 & 28.8 & 34.8 & 38.0 & 41.0 & 43.3 & 71.6 \\
\hline 8 & May & 1983 & 5.67 & 46.4 & 53.0 & 60.0 & 63.8 & 66.0 & 90.4 \\
\hline 9 & November & 1983 & .91 & 7.48 & 9.20 & 10.8 & 11.4 & 12.2 & 66.0 \\
\hline 10 & July & 1984 & 7.10 & 25.5 & 28.3 & 31.8 & 34.0 & 35.5 & 44.0 \\
\hline 11 & February & 1985 & .90 & 8.55 & 10.3 & 11.4 & 12.4 & 13.8 & 92.5 \\
\hline 12 & May & 1985 & 2.70 & 24.3 & 27.0 & 30.0 & 31.6 & 33.2 & 45.0 \\
\hline 13 & August & 1985 & .62 & 5.00 & 5.78 & 6.60 & 7.01 & 8.14 & 64.0 \\
\hline 14 & November & 1985 & .94 & 7.74 & 8.89 & 9.80 & 10.5 & 11.2 & 55 \\
\hline 15 & February & 1986 & 1.00 & 8.45 & 9.69 & 10.4 & 11.0 & 12.0 & 655 \\
\hline 16 & May & 1986 & 2.79 & 3.79 & 4.10 & 4.40 & 4.80 & 6.00 & 98.3 \\
\hline 17 & August & 1986 & 3.98 & 45.7 & 48.4 & 51.4 & 52.9 & 55.0 & 78.4 \\
\hline 18 & November & 1986 & 1.07 & 19.0 & 19.8 & 20.9 & 21.7 & 22.3 & 26.1 \\
\hline 19 & July & 1987 & 9.80 & 12.4 & 12.9 & 13.5 & 14.0 & 14.9 & 47.2 \\
\hline 20 & October & 1987 & .73 & 6.56 & 7.10 & 7.42 & 7.9 & 8.90 & 8,450 \\
\hline 21 & May & 1988 & 1.68 & 15.5 & 16.4 & 16.9 & 17.4 & 18.3 & 85.5 \\
\hline 22 & November & 1988 & 5.90 & 18.4 & 19.0 & 19.5 & 20.1 & 20.9 & 38.2 \\
\hline 23 & May & 1989 & 6.30 & 7.74 & 8.30 & 8.64 & 8.9 & 9.40 & 90.4 \\
\hline 24 & November & 1989 & 4.00 & 38.4 & 41.5 & 43.2 & 44.4 & 46.0 & 157.9 \\
\hline
\end{tabular}


Table 3.--Summary statistics obtained from analysis of site-operator results for pH measurements obtained from intersite-comparison studies

\begin{tabular}{|c|c|c|c|c|}
\hline $\begin{array}{l}\text { Intersite- } \\
\text { comparison } \\
\text { study } \\
\text { number }\end{array}$ & $\begin{array}{l}\text { Number } \\
\text { of site } \\
\text { operators } \\
\text { responding }\end{array}$ & $\begin{array}{l}\text { Median } \\
\text { for all } \\
\text { responding } \\
\text { site operators }\end{array}$ & $\begin{array}{c}\text { F-pseudo- } \\
\text { sigma }\end{array}$ & $\begin{array}{l}\text { Percentage of } \\
\text { site operators } \\
\text { that met the } \\
\text { measurement- } \\
\text { accuracy } \\
\text { criteria }\end{array}$ \\
\hline 1 & 7 & 3.02 & 0.26 & 57 \\
\hline 2 & 32 & 4.08 & .25 & 41 \\
\hline 3 & 32 & 4.47 & .25 & 34 \\
\hline 4 & 57 & 4.29 & .07 & 65 \\
\hline 5 & 73 & 4.29 & .12 & 59 \\
\hline 6 & 85 & 4.57 & .13 & 53 \\
\hline 7 & 93 & 4.03 & .10 & 66 \\
\hline 8 & 101 & 3.84 & .10 & 64 \\
\hline 9 & 118 & 4.61 & .11 & 60 \\
\hline 10 & 120 & 4.12 & .07 & 71 \\
\hline 11 & 163 & 4.55 & .10 & 65 \\
\hline 12 & 162 & 4.13 & .07 & 72 \\
\hline 13 & 172 & 4.79 & .11 & 66 \\
\hline 14 & 165 & 4.61 & .09 & 73 \\
\hline 15 & 173 & 4.60 & .07 & 78 \\
\hline 16 & 170 & 4.96 & .10 & 65 \\
\hline 17 & 170 & 3.92 & .04 & 83 \\
\hline 18 & 168 & 4.32 & .05 & 88 \\
\hline 19 & 175 & 4.50 & .07 & 83 \\
\hline 20 & 167 & 4.73 & .09 & 71 \\
\hline 21 & 177 & 4.40 & .04 & 88 \\
\hline 22 & 176 & 5.06 & .11 & 94 \\
\hline 23 & 182 & 4.68 & .08 & 75 \\
\hline 24 & 186 & 4.01 & .04 & 91 \\
\hline
\end{tabular}

${ }^{1} \mathrm{~F}$-pseudosigma $=\frac{75 \text { th }-25 \text { th percentile of all responding site operators }}{1.349}$

${ }^{2}$ Accuracy criteria for $\mathrm{pH}$ determintations are \pm 0.10 unit if median $\mathrm{pH}$ is 5.0 or less; if median $\mathrm{pH}$ exceeds 5.0 , the accuracy criteria are $\pm 0.30 \mathrm{pH}$ unit. 
A nonparametric correlation analysis was used to assess the relation between the ability of site operators to meet measurement-accuracy criteria and intersite-comparison study number. Nonparametric regression analysis was used to assess the trend in site-operator ability to meet measurement-accuracy criteria. Nonparametric tests are appropriate for data that do not consistently meet all the assumptions necessary for using parametric statistical tests, including equal variances and normal distributions (Conover, 1980). The Spearman rank correlation test was used as a nonparametric measure of the association between two variables; nonparametric rank regression analysis provided a measure of their linear relation (Conover, 1980). Using the intersite-comparison study number as a substitute for time, a statistically significant positive Spearman rank correlation coefficient between the percentage of site operators successfully meeting measurement-accuracy criteria for $\mathrm{pH}$ determinations and time was determined $(\alpha=0.05, r=0.88)$. The nonparametric rank regression equation between the percentage of site operators successfully meeting measurement-accuracy criteria for $\mathrm{pH}$ determinations and the intersite-comparison study number is depicted in figure 2.

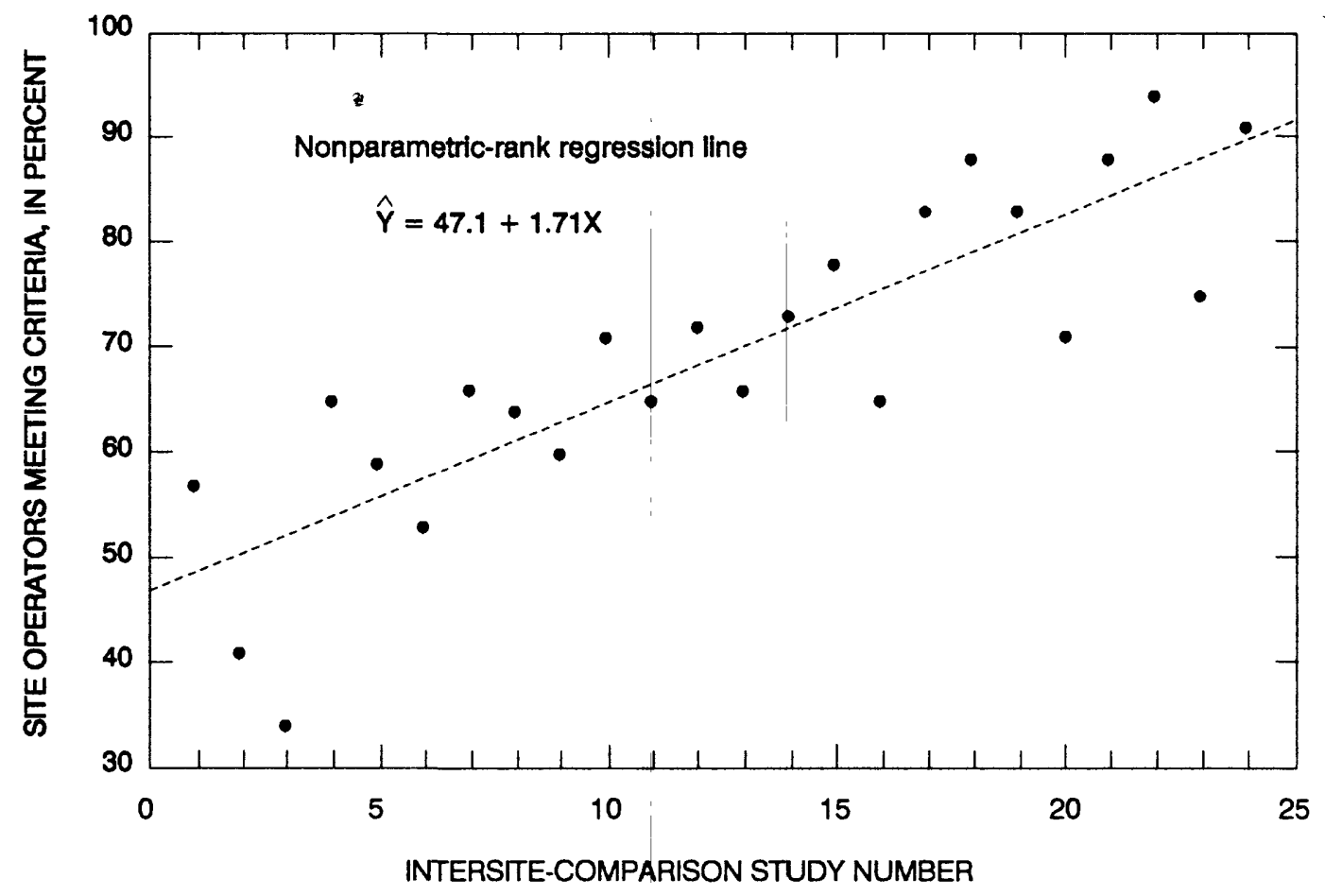

Figure 2.--Relation between site operators meeting measurement-accuracy criteria for $\mathrm{pH}$ determinations, in percent, and intersite-comparison study number. 
pH Determinations Outside Measurement-Accuracy Criteria

A total of 805 of the $3,124 \mathrm{pH}$ determinations (26 percent) did not meet NOS measurement-accuracy criteria in studies 1-24. Analysis of these determinations yields the following observations:

(1) Of the $\mathrm{pH}$ determinations that did not meet the measurement-accuracy criteria, 61 percent missed the goals by $0.10 \mathrm{pH}$ unit or less; 74 percent missed the goals by $0.25 \mathrm{pH}$ unit or less (fig. 3).

(2) A total of 13 percent of the $\mathrm{pH}$ determinations that did not meet the measurement-accuracy criteria missed the goals by $0.50 \mathrm{pH}$ unit or more.

(3) The operators of a small percentage of the NADP/NTN sites accounted for a disproportionately large percentage of determinations that failed to meet the measurement-accuracy criteria: the operators of 32 sites, about 12 percent of the sites that participated in intersite-comparison studies 1-24, accounted for 29 percent of the $\mathrm{pH}$ determinations outside the acceptable criteria for measurement accuracy.

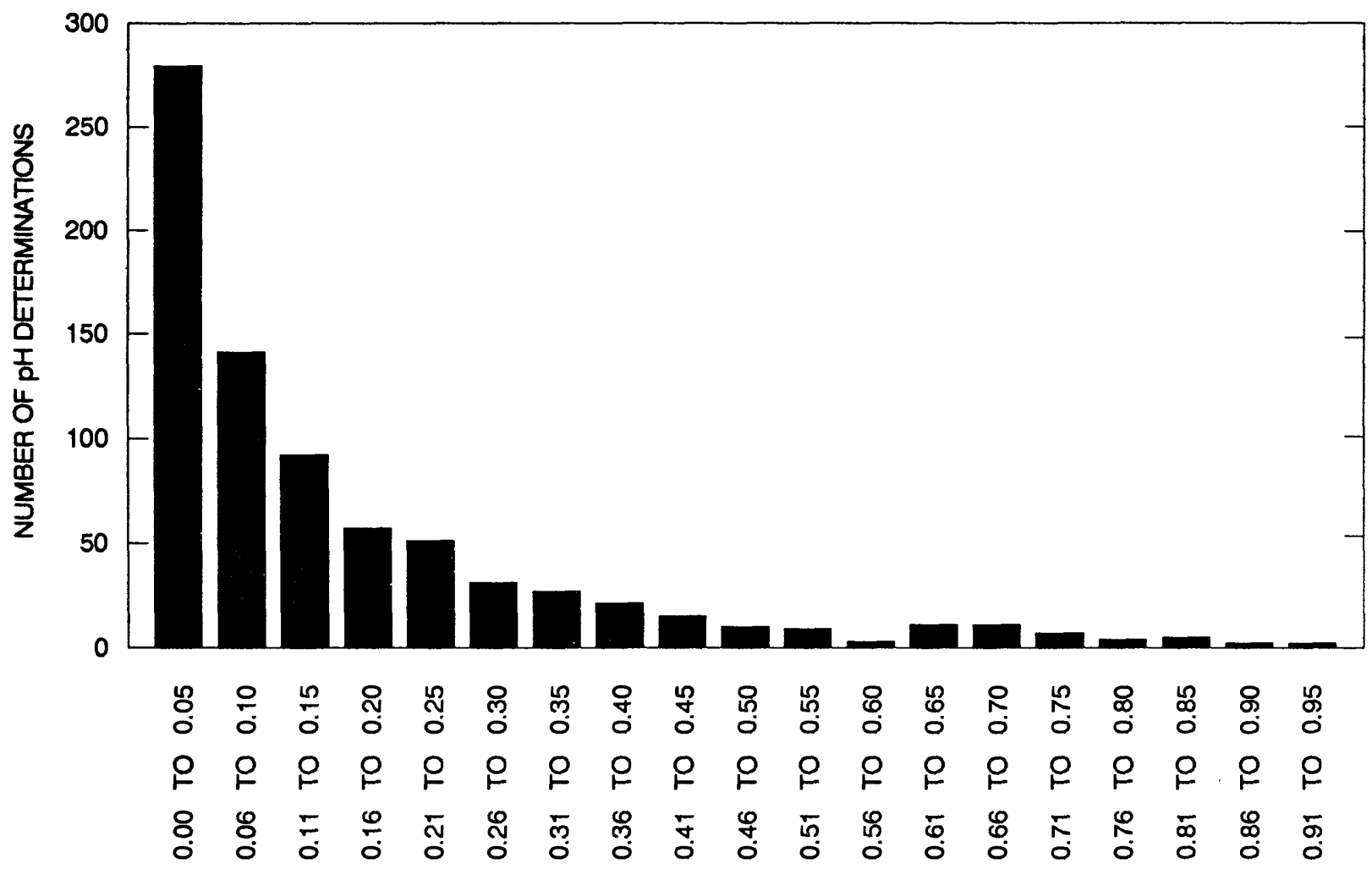

PH MEASUREMENT ERROR, IN UNITS OF pH

Figure 3.--Frequency distribution of measurement error for $\mathrm{pH}$ determinations that failed to meet the measurement-accuracy criteria in studies 1-24. $\mathrm{pH}$ measurement error was computed as the absolute difference between a reported $\mathrm{pH}$ value and the $\mathrm{pH}$ value corresponding to the nearest measurement-accuracy limit as defined by the Network Operation Subcommittee. 


\section{Success Rates For Achieving pH Measurement-Accuracy Criteria}

Because many NADP/NTN sites have had several site operators, a success rate for achieving $\mathrm{pH}$ measurement-accuracy criteria was determined for each site whose operators actively participated in the intersite-comparison program, rather than for individual site operators. The success rate was calculated as :

Success Rate $=$

Number of times the operators of a site met accuracy criteria $\times 100$

The success rates for sites with actively participating operators in studies 1-10 (sites whose operators participated at least five times) were compared with the success rates for sites with actively participating operators in studies 11-24. The percentage of sites whose operators achieved success rates between 80 and 100 percent increased from 29 percent in studies 1-10 to 58 percent in studies 11-24. Whereas the operators of many sites have good success rates of achieving the $\mathrm{pH}$ measurement-accuracy criteria, the operators of 32 sites have success rates of 50 percent or less. The median success rate for the operators of this group of sites was 39 percent. These sites were distributed among all geographic regions of the United States, including the northeast where concern about acidic wet deposition and its effects is greatest.

of the 32 sites whose operators met the measurement-accuracy criteria 50 percent of the time or less, 27 registered brief yet distinct periods when their performance was acceptable. For example, it was not uncommon for a site whose operators met the measurement-accuracy criteria in only 7 of 20 studies in which they participated to have recorded 6 of these successes consecutively. A statistical test known as a runs test verified this non-random pattern of success and failure (Dixon and Massey, 1969). Changes in siteoperator personnel are the most likely explanation for this pattern of performance.

\section{Differences Between Measured and Median $\mathrm{pH}$}

Determining the success or failure of individual site operators to meet the NOS measurement-accuracy criteria and determining success rates for each site are both useful means of evaluating the accuracy of $\mathrm{pH}$ determinations made in the intersite-comparison program. Additional insight regarding measurement precision can be gained by analyzing the differences between the values reported by the individual site operators and the network median values.

The frequency distribution of differences between measured and median $\mathrm{pH}$ for all pH determinations that were made during intersite-comparison studies 1-24 is shown in figure 4. For all 24 studies, 49 percent of the determinations was within $0.05 \mathrm{pH}$ unit of the median value, 82 percent was within $0.15 \mathrm{pH}$ unit of the median, and 90 percent was within $0.25 \mathrm{pH}$ unit of the median. The interquartile range of measured minus median $\mathrm{pH}$ for each 


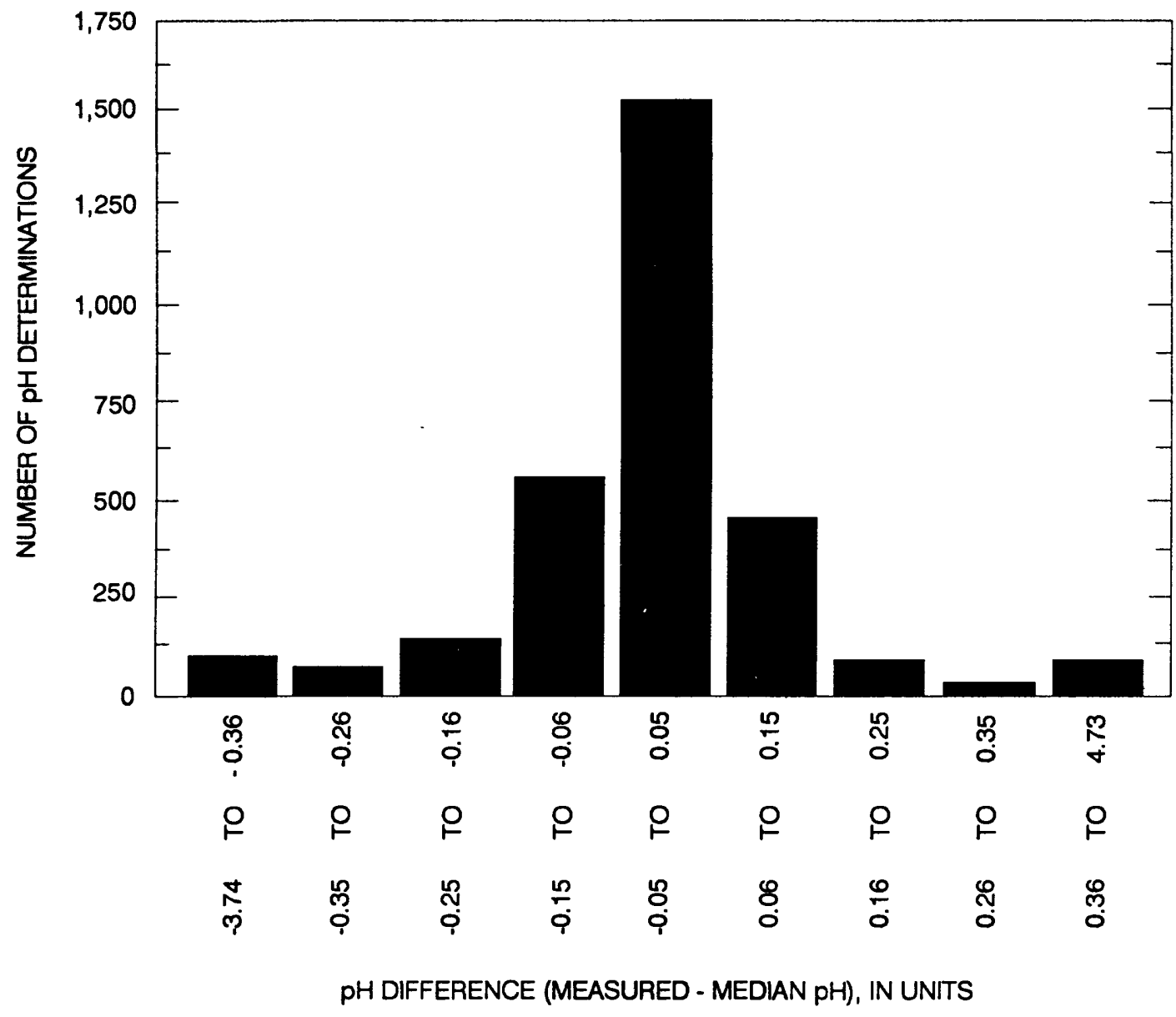

Figure 4.--Frequency distribution of differences between measured and median $\mathrm{pH}$ for studies 1-24.

intersite-comparison study is shown in figure 5A. The interquartile range is defined as the distance from the first to the third quartile. The first quartile is equal to the 25 th percentile of the data, and the third quartile is equal to the 75th percentile (Chambers and others, 1983). The size of the interquartile range provides a measure of the degree of similarity among independent measurements of the same quantity, and is indicative of the overall precision of the site operators participating in each study. The median $\mathrm{pH}$ for each intersite-comparison study is shown in figure 5B. 

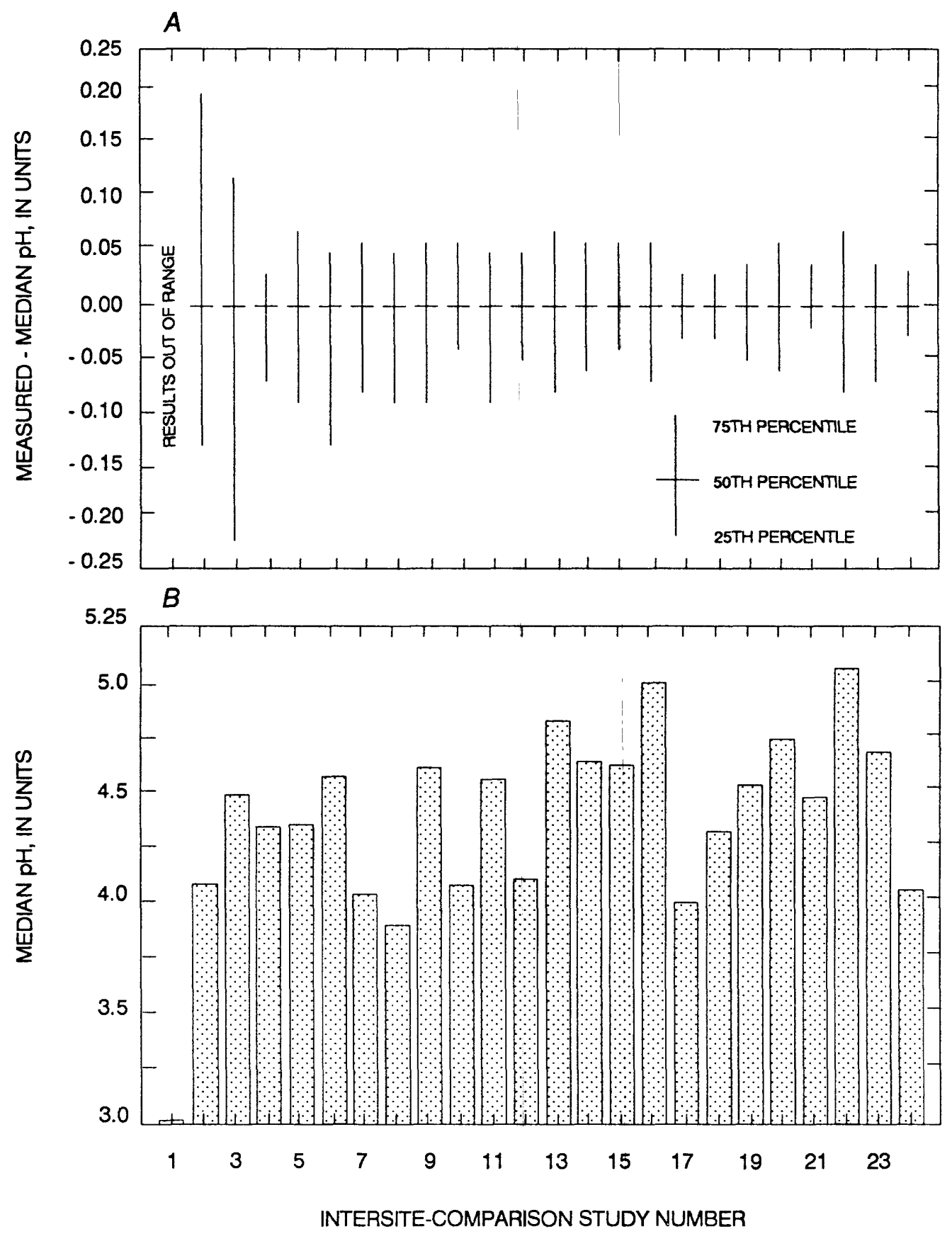

Figure 5.--A, Interquartile range of measured minus median $\mathrm{pH}$ for each intersite-comparison study; $B$, Median $\mathrm{pH}$ for each intersitecomparison study. 
To determine if the selected target $\mathrm{pH}$ affected the degree of similarity among $\mathrm{pH}$ measurements reported by the site operators in a given study, a nonparametric correlation test was used to assess the degree of association between the measured minus median interquartile range and the median $\mathrm{pH}$ of the reference solution. For studies 1-10, the Spearman rank correlation coefficient between the measured minus median interquartile range and intersitecomparison study median $\mathrm{pH}$ was -0.05 , which was not statistically significant $(\alpha=0.05)$. For studies 11-24, however, the Spearman rank correlation coefficient was 0.85 , which was statistically significant $(\alpha=0.05)$. The amount of variability in reported $\mathrm{pH}$ values increased monotonically with median $\mathrm{pH}$ in studies 11-24; there was more variability in the reported $\mathrm{pH}$ values when the median $\mathrm{pH}$ of the reference solution was relatively larger.

\section{Evaluation of Specific-Conductance Determinations Using Network Operations Subcommittee Measurement-Accuracy Criteria}

The measurement-accuracy criteria established by the NOS for specificconductance determinations are $\pm 4.0 \mu \mathrm{S} / \mathrm{cm}$. These measurement-accuracy criteria are used for all intersite-comparison studies, regardless of the median specific conductance of the reference solution. Median specific conductance of the reference solutions ranged from 4 to $60 \mu \mathrm{s} / \mathrm{cm}$ in intersitecomparison studies 1-24.

During intersite-comparison studies $1-24,3,113$ specific-conductance determinations were done. Of this total, 2,692 ( 86 percent) met the NOS measurement-accuracy criteria. Table 4 depicts the percentage of site operators that met the measurement-accuracy criteria for specific conductance, the number of site operators responding, and the F-pseudosigma for each intersite-comparison study. A scatterplot depicting the percentage of site operators that met the specific-conductance accuracy criteria on an individual study basis is shown in figure 6 .

The percentage of site operators reporting specific-conductance values within the NOS measurement-accuracy criteria increased from an average of 73 percent in studies $1-10$ to an average of 90 percent in studies $11-24$. The increase in the percentage of site operators that met the measurement-accuracy criteria in studies 11-24 compared with studies 1-10 was to a large extent associated with differences in the median specific conductance of the reference solutions used in studies 1-10 and studies 11-24. From the start of the intersite program, site operators have had little difficulty meeting the measurement-accuracy goals for specific conductance when the median specific conductance was relatively small. The percentage of site operators reporting specific-conductance values that met the NOS measurement-accuracy criteria varied between 88 and 97 percent when the median specific conductance was less than $25 \mu \mathrm{s} / \mathrm{cm}$. When the median specific conductance of the reference solution was between 30 to $60 \mu \mathrm{S} / \mathrm{cm}$, only 38 to 82 percent of the participating site operators was able to meet the measurement-accuracy criteria (reference solutions with median specific-conductance values between 25 and $30 \mu \mathrm{S} / \mathrm{cm}$ were not used in studies 1-24). The median specific conductance was less than $25 \mu \mathrm{S} / \mathrm{cm}$ in only four of the first ten studies; in studies $11-24$, the median specific conductance was in this range in eleven studies. 
Table 4.--Summary statistics obtained from analysis of site-operator results for specific-conductance measurements obtained

from intersite-comparison studies

$[\mu \mathrm{S} / \mathrm{cm}$, microsiemens per centimeter at 25 degrees Celsius]

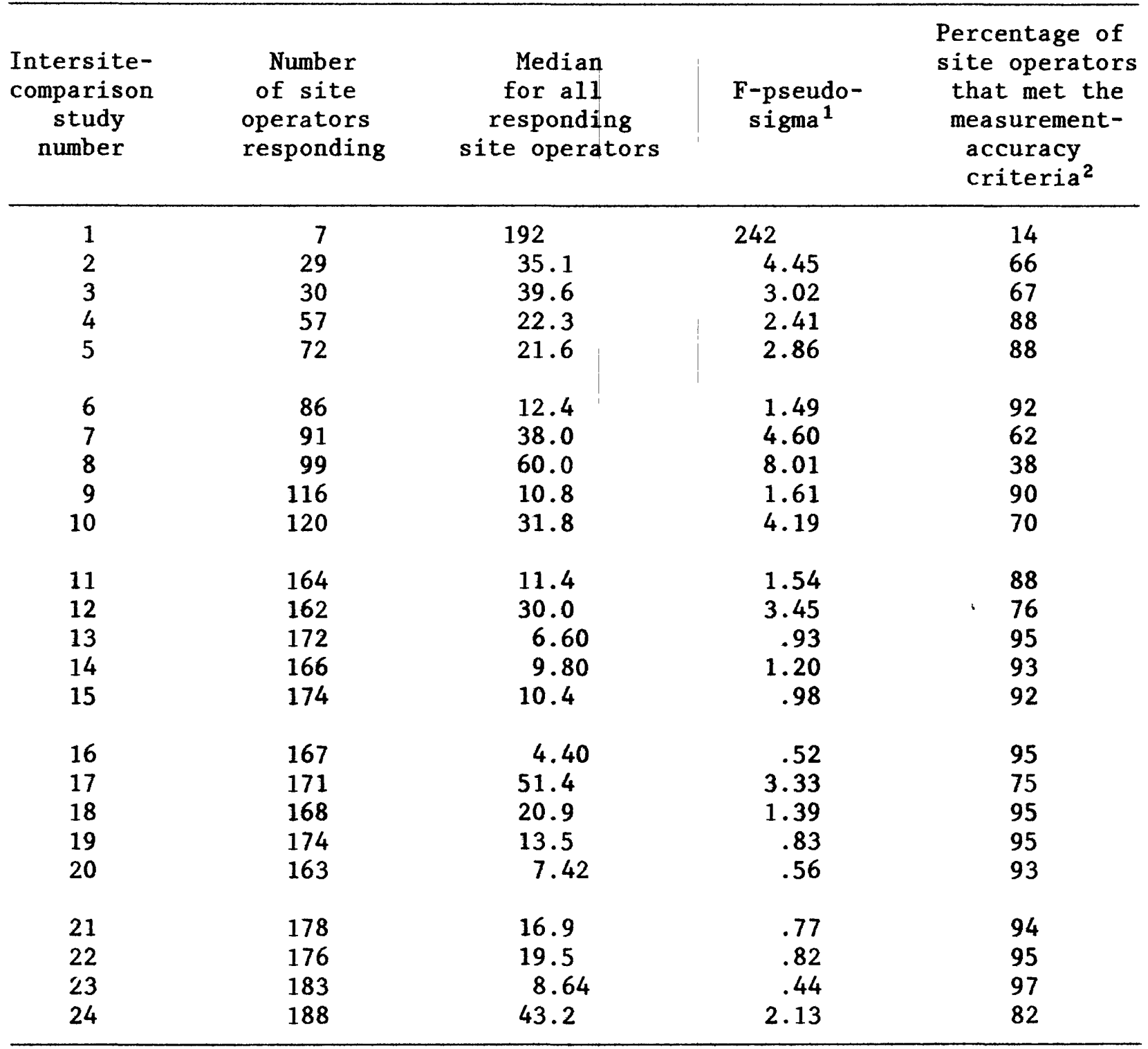

${ }^{1} \mathrm{~F}$-psuedosigma $=\frac{75 \mathrm{th}-25 \mathrm{th} \text { percentile of all responding site operators }}{1.349}$

${ }^{2}$ Accuracy criteria for specific-conductance determinations are \pm 4.0 microsiemens per centimeter at 25 degrees Celsius. 


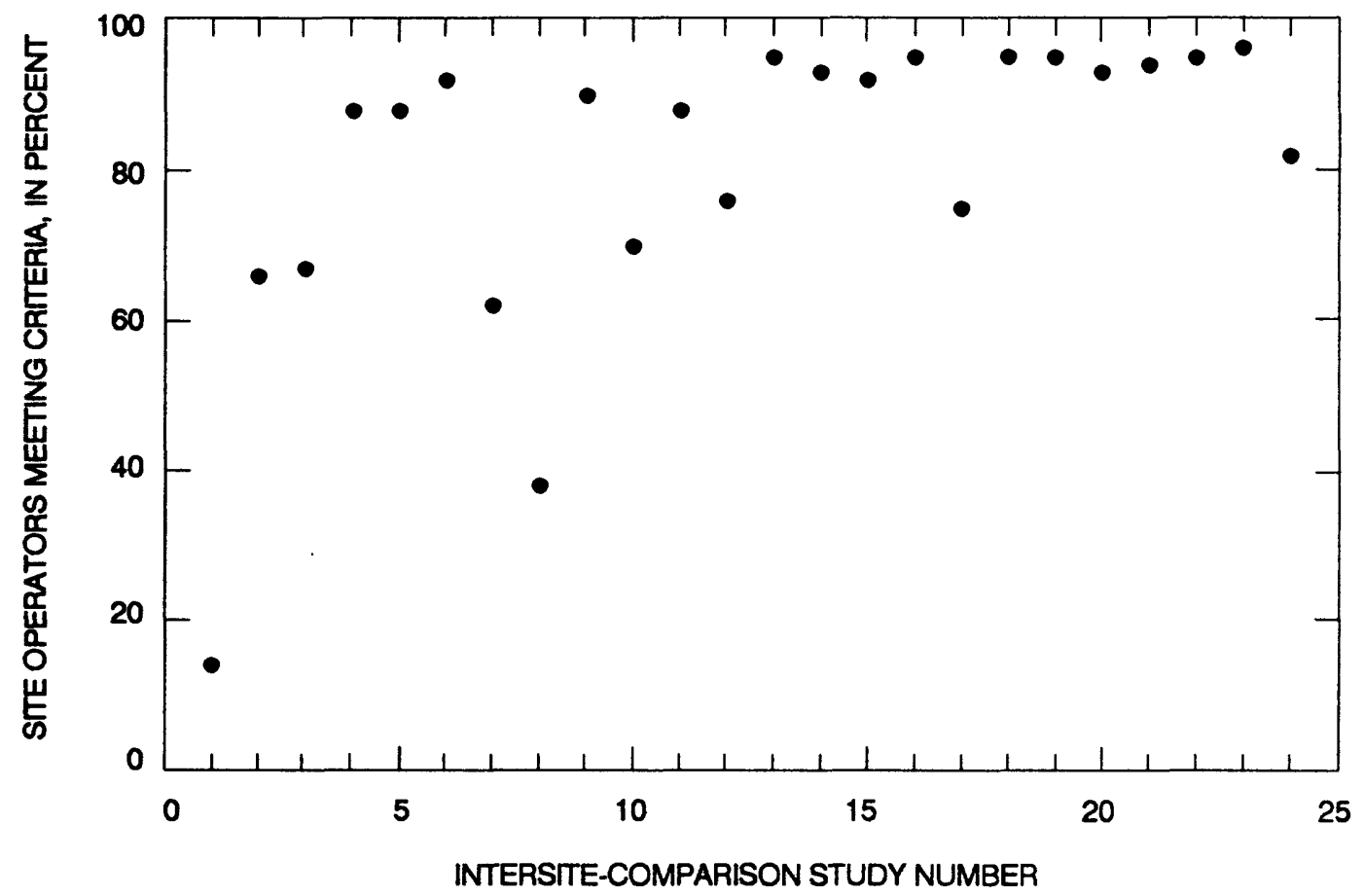

Figure 6.--Comparison of site operators meeting measurement-accuracy criteria for specific-conductance determinations and intersitecomparison study number.

\section{Specific-Conductance Determinations Outside Measurement-Accuracy Criteria}

A total of 421 of the 3,113 specific-conductance determinations (14 percent) did not meet the NOS measurement-accuracy criteria in studies 1-24. Analysis of these determinations yields the following observations :

(1) The percentage of site operators that failed to meet the measurementaccuracy criteria by a wide margin (more than $8 \mu \mathrm{S} / \mathrm{cm}$ ) was about the same as the percentage that missed the measurement-accuracy criteria by a narrow margin $(2 \mu \mathrm{S} / \mathrm{cm}$ or less). Of the determinations that failed to meet the measurement-accuracy criteria, 40 percent were within $2 \mu \mathrm{S} / \mathrm{cm}$, whereas 32 percent of the failed determinations missed the measurementaccuracy criteria by more than $8 \mu \mathrm{S} / \mathrm{cm}$.

(2) The operators of a small percentage of sites accounted for a disproportionately large percentage of determinations that failed to meet the measurement-accuracy criteria: the operators of 22 sites, less than 9 percent of the total number of sites that participated in intersitecomparison studies 1-24, accounted for 16 percent of the specificconductance determinations that were outside the accuracy criteria. 
A success rate for achieving the NOS accuracy criteria for specificconductance measurements was determined for each site whose operators actively participated in the intersite-comparison program (equation 1). The operators of most sites had excellent success rates of achieving NOS measurementaccuracy criteria for specific-conductance measurements. About 67 percent of the sites whose operators participated in at least five studies achieved success rates of 85 percent or better. There was, however, a small group of sites whose operators achieved success rates of 60 percent or less, with a median success rate of 47 percent. Ten of the 22 sites whose operators had success rates of 60 percent or less for specific-conductance determinations were among the 32 sites whose operators had the poorest success rates of achieving NOS measurement-accuracy criteria for $\mathrm{pH}$ determinations.

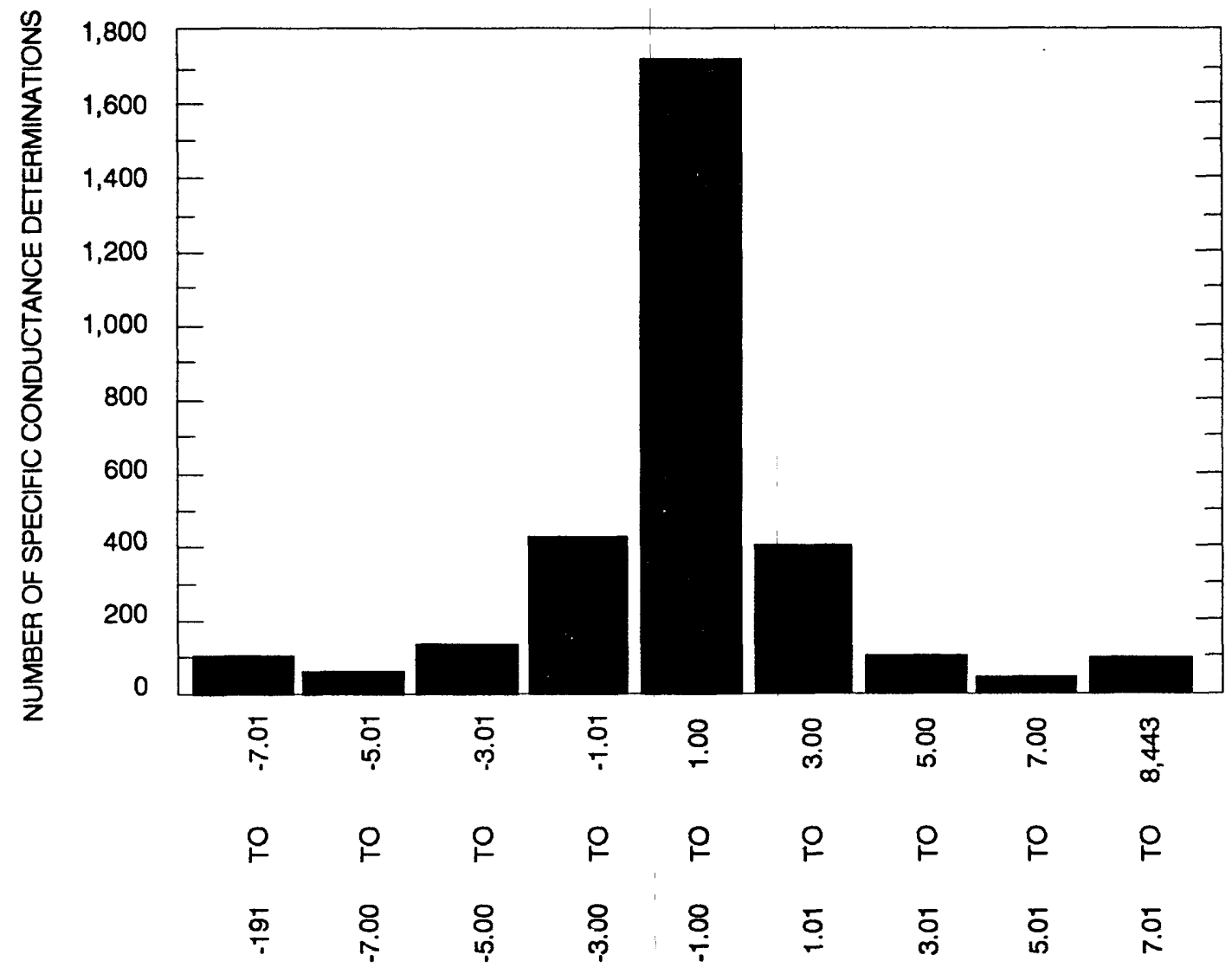

SPECIFIC CONDUCTANCE DIFFERENCE (MEASURED - MEDIAN), IN MICROSIEMENS PER CENTIMETER AT 25 DEGREES CELSIUS

Figure 7.--Frequency distribution of differences between measured and median specific conductance for studies 1-24. 


\section{Differences between Measured and Median Specific Conductance}

The frequency distribution of differences between the measured and the median specific conductance for all determinations that were made during intersite-comparison studies $1-24$ is shown in figure 7 . For the 24 studies, a total of 55 percent of the determinations was within $\pm 1 \mu \mathrm{S} / \mathrm{cm}$ of the median values of the individual studies, and 82 percent was within $\pm 3 \mu \mathrm{S} / \mathrm{cm}$ of the median. The percentage of determinations approximating the median values of the individual studies indicates a large degree of measurement precision on an overall basis. The interquartile range of measured minus median specificconductance values was, however, strongly affected by the specific conductance of the reference solution. When the median specific conductance of the reference solution was less than $25 \mu \mathrm{S} / \mathrm{cm}$, the interquartile range generally was much smaller than when the median specific conductance exceeded $25 \mu \mathrm{S} / \mathrm{cm}$ (figs. 8A and 8B). For example, intersite-comparison study 8, which had a reference solution with one of the largest median specific-conductance values $(60 \mu \mathrm{S} / \mathrm{cm})$, also had one of the largest measured minus median interquartile ranges $(11 \mu \mathrm{S} / \mathrm{cm})$. For studies $1-24$, the Spearman rank correlation coefficient between the measured minus median interquartile range and the median specific conductance was statistically significant $(\alpha=0.05, r=0.85)$.

\section{EVALUATION OF NETWORK OPERATIONS SUBCOMMITTEE MEASUREMENT-ACCURACY CRITERIA}

The question of whether the established measurement-accuracy criteria are appropriate has been raised periodically by various members of the NOS. For example, Schroder and others (1987) commented that the criteria established for specific-conductance measurements should be changed. The authors noted that the percentage of site operators meeting the accuracy criteria was only 38 percent for study 8 (May 1983) when the median specific conductance of the reference solution was $60 \mu \mathrm{S} / \mathrm{cm}$.

For each intersite-comparison study, a different reference solution is prepared. The target $\mathrm{pH}$ is selected between 3.8 and 5.3 units, with consideration given to the $\mathrm{pH}$ of preceding studies. The specific conductance of the reference solution is dependent upon the selected target $\mathrm{pH}$ and ranged between 4 and $60 \mu \mathrm{S} / \mathrm{cm}$ in studies 1-24. The measurement-accuracy criteria established by the NOS for $\mathrm{pH}$ determinations are $\pm 0.10 \mathrm{pH}$ unit of the most probable value if the $\mathrm{pH}$ of the reference solution is 5.0 or less. Two separate studies with median $\mathrm{pH}$ values of 3.84 and 4.96 , therefore, applied the same measurementaccuracy criteria, even though a reference solution with a $\mathrm{pH}$ of 3.84 contains over ten times the hydrogen ion concentration that a reference solution with a $\mathrm{pH}$ of 4.96 contains. Regardless of the specific conductance of the reference solution, the measurement-accuracy criteria established by the NOS are $\pm 4.0 \mu \mathrm{S} / \mathrm{cm}$. The accuracy criteria thus allow for \pm 100 percent measurement error if the target specific conductance is $4 \mu \mathrm{S} / \mathrm{cm}$, but only \pm 6.7 percent measurement error if the target specific conductance is $60 \mu \mathrm{S} / \mathrm{cm}$. Nonparametric statistical tests were used to evaluate the appropriateness of the NOS measurement-accuracy criteria for both $\mathrm{pH}$ and specific-conductance determinations. 


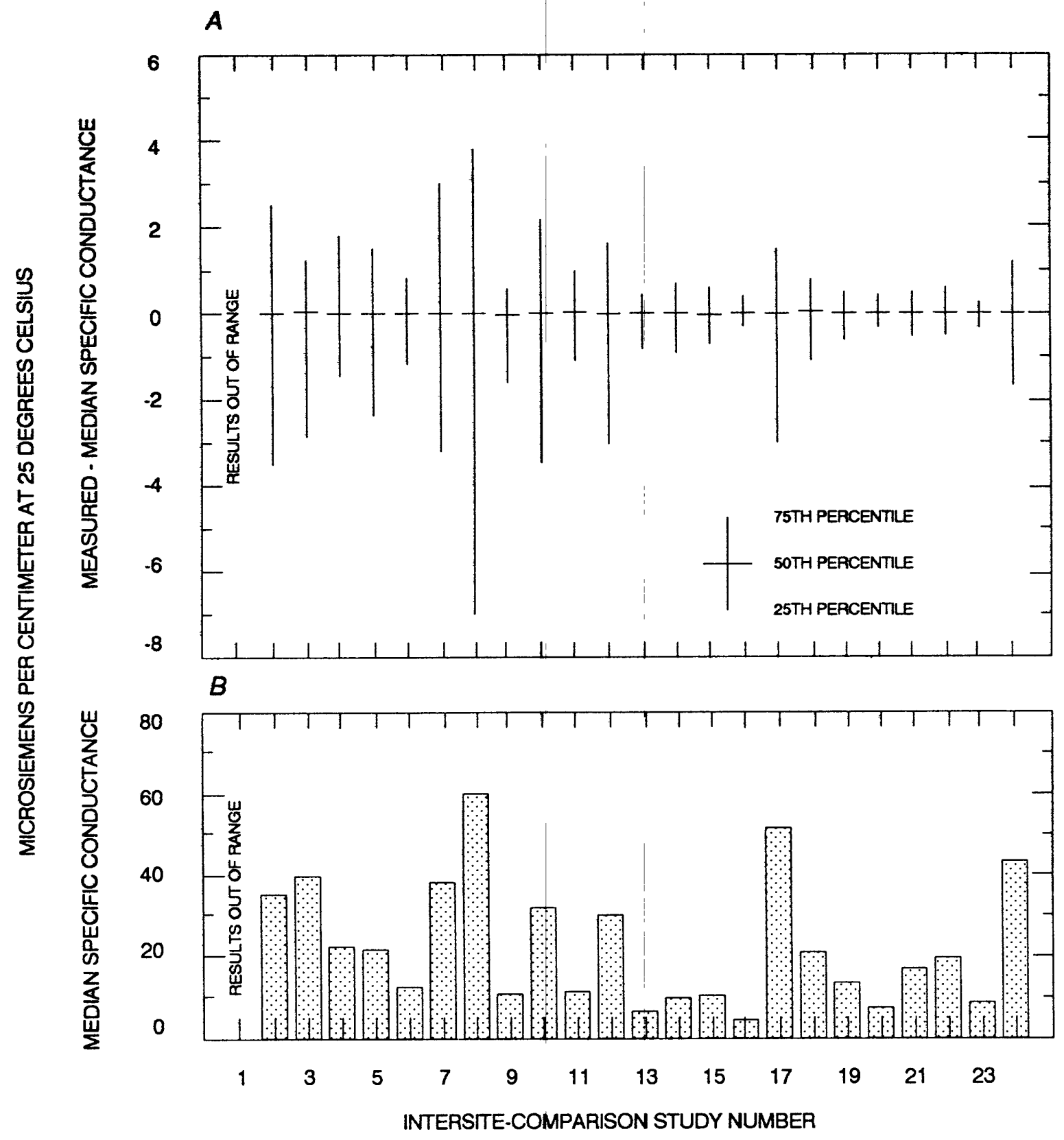

Figure 8.--A, Interquartile range of measured minus median specific conductance for each intersite-comparison study; $B$, Median specific conductance for each intersite-comparison study. 
Scatterplots of the relation between the percentage of site operators that met the NOS measurement-accuracy criteria and the median $\mathrm{pH}$ of the reference solution are shown in figures $9 \mathrm{~A}$ and $9 \mathrm{~B}$. For studies 1-10, the Spearman rank correlation coefficient between the median $\mathrm{pH}$ of the reference solutions used in the intersite-comparison program and the percentage of site operators that met $\mathrm{pH}$ measurement-accuracy criteria was not statistically significant $(\alpha=0.05, r=-0.24)$. Excluding study 22 because of the different $\mathrm{pH}$ measurement-accuracy criteria that were applied, a statistically significant Spearman rank correlation coefficient between the median $\mathrm{pH}$ of the reference solution and the percentage of site operators achieving the accuracy criteria was determined for studies 11-24 $(\alpha=0.05, \mathrm{r}=-0.71)$. During studies 11-24, a relatively larger percentage of site operators met the $\mathrm{pH}$ accuracy criteria when a reference solution with a relatively smaller median $\mathrm{pH}$ was used. The median $\mathrm{pH}$ was between 4.50 and $5.00 \mathrm{pH}$ units in two of the first ten studies; in studies 11-24, the median $\mathrm{pH}$ was in this range in eight of the studies. The increase in the percentage of site operators meeting the accuracy criteria in studies 11-24 compared with studies $1-10$ was in spite of the fact that generally larger median $\mathrm{pH}$ reference solutions were used in studies 11-24.

For studies 1-24, the Spearman rank correlation coefficient between the percentage of site operators meeting specific-conductance criteria and the median specific conductance of the reference solution was statistically significant $(\alpha=0.05, r=-0.82)$. Most of the variability in the percentage of site operators that met the specific-conductance accuracy criteria in intersite-comparison studies $1-24$ was associated with the median specific conductance of the reference solution. The nonparametric rank regression equation between the percentage of site operators meeting specific-conductance criteria and the median $\mathrm{pH}$ of the reference solution was $\mathrm{Y}=105.3-0.79(\mathrm{X})$ (fig. 10).

To facilitate the evaluation of $\mathrm{pH}$ and specific-conductance determinations, the current NOS measurement-accuracy criteria need to be revised. In place of the current accuracy criteria of \pm 0.10 or \pm 0.30 unit for $\mathrm{pH}$ and $\pm 4.0 \mu \mathrm{S} / \mathrm{cm}$ for specific conductance, a continuum of accuracy criteria could be established. New measurement-accuracy criteria could, for example, be based on statistical quality-control techniques (Taylor, 1987). Alternatively, adjustable ranges of acceptable percent measurement error depending on the target values of the reference solution could be established. 


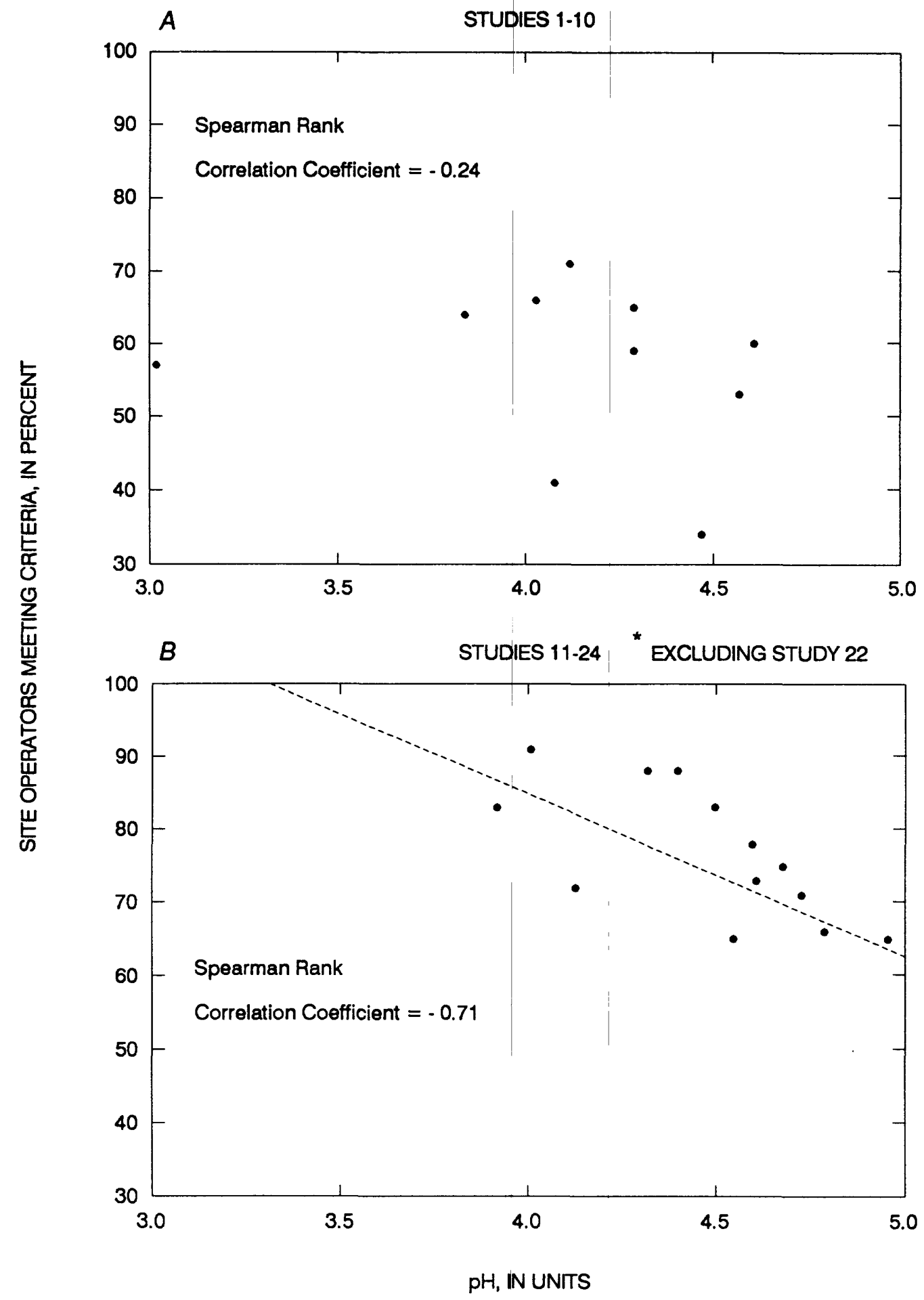

Figure 9.--A, Relation between site operators meeting $\mathrm{pH}$ measurementaccuracy criteria, in percent, and the median $\mathrm{pH}$ of the intersitecomparison study reference solution in studies $1-10 ; B$, Relation between site operators meeting $\mathrm{pH}$ measurement-accuracy criteria, in percent, and the median $\mathrm{pH}$ of the intersite-comparison study reference solution in studies 11-24, excluding study 22 .

*Study 22 was excluded because accuracy criteria of $\pm 0.10 \mathrm{pH}$ unit were applied for all studies except 22. Accuracy criteria of $\pm 0.30 \mathrm{pH}$ unit were used in study 22 . 


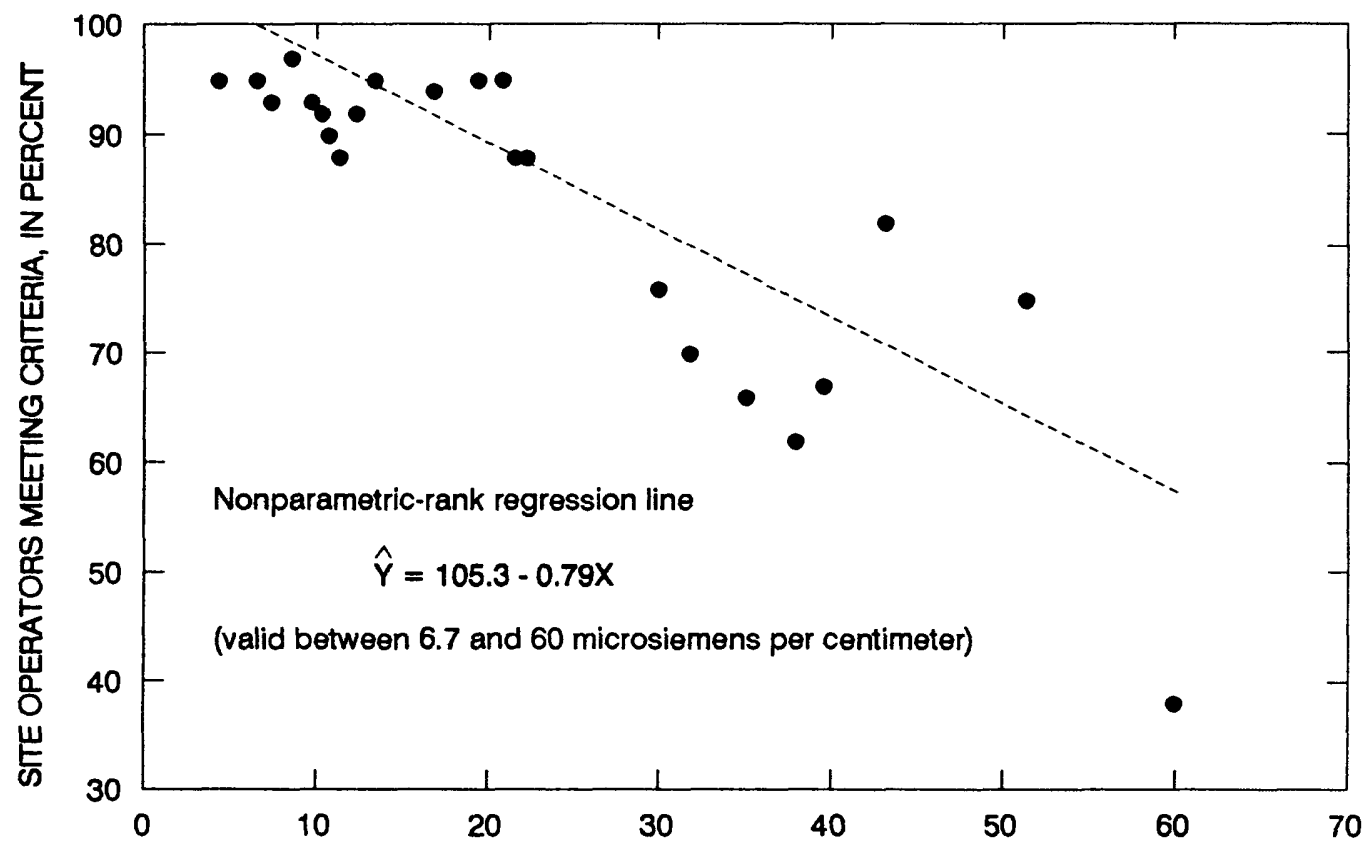

SPECIFIC CONDUCTANCE, IN MICROSIEMENS PER CENTIMETER AT 25 DEGREES CELSIUS

Figure 10.--Relation between site operators meeting specific-conductance measurement-accuracy criteria, in percent, and the median specific conductance of the intersite-comparison study reference solution.

\section{SUMMARY}

The intersite-comparison program is an ongoing, external qualityassurance program used to assess the ability of NADP/NTN site operators to make accurate and precise $\mathrm{pH}$ and specific conductance measurements. During intersite-comparison studies $1-24,3,124 \mathrm{pH}$ determinations were made. Of this total, NOS measurement-accuracy criteria were met for $2,319 \mathrm{pH}$ determinations (74 percent). Because of significant changes in the operating protocol of the network, it is meaningful to compare the results of studies 1-10 with the results of studies 11-24. These changes included the decision by the NOS to supply site operators with uniform-quality $\mathrm{pH}$ electrodes and the initiation of site-visitation and site-operator training programs. The percentage of site operators reporting $\mathrm{pH}$ values within NOS measurement-accuracy criteria for the network increased from an average of 61 percent for intersite-comparison studies 1-10 to an average of 78 percent for studies 11-24. 
Between the completion of intersite-comparison study 1 and study 24 , there was an improving trend in the ability of site operators to successfully meet the accuracy criteria for $\mathrm{pH}$ determinations. The percentage of site operators successfully meeting the measurement-accuracy criteria was larger in recent studies compared with the percentage meeting the criteria in earlier studies. Nonparametric correlation and regression analysis techniques were used to determine if there was a statistically significant trend in the ability of site operators to meet measurement-accuracy criteria.

To determine whether the selected target $\mathrm{pH}$ affected the degree of similarity (that is, the precision) among $\mathrm{pH}$ measurements reported by the site operators in a given study, a nonparametric correlation test was used to assess the degree of association between the measured minus median interquartile range and the median $\mathrm{pH}$ of the reference solution. For studies 11-24, the size of the measured minus median interquartile range increased monotonically with median $\mathrm{pH}$; there was less precision among reported $\mathrm{pH}$ values when the median $\mathrm{pH}$ of the reference solution was relatively larger.

No statistically significant correlation between the median $\mathrm{pH}$ of the reference solution and the percentage of site operators achieving NOS measurement-accuracy criteria was determined for intersite-comparison studies 1-10. Excluding study 22 because of the different $\mathrm{pH}$ measurement-accuracy criteria that were applied, a statistically significant Spearman rank correlation coefficient between the median $\mathrm{pH}$ of the reference solution and the percentage of site operators achieving the accuracy criteria was determined for studies 11-24. A relatively larger percentage of site operators met the accuracy criteria for $\mathrm{pH}$ in studies 11-24 when the median $\mathrm{pH}$ of the reference solution was relatively smaller. The median $\mathrm{pH}$ was between 4.50 and $5.00 \mathrm{pH}$ units in two of the first ten studies; in studies 11-24, the median pH was in this range in eight studies. The increase in the percentage of site operators that met the accuracy criteria in studies 11-24 compared with studies 1-10 was in spite of the fact that the reference solutions used in studies 11-24 generally had larger median $\mathrm{pH}$ values than the reference solutions used in studies 1-10.

The percentage of site operators reporting specific-conductance values within the NOS measurement-accuracy criteria increased from an average of 73 percent in studies 1-10 to an average of 90 percent in studies 11-24. Between 88 and 97 percent of the participating site operators met the accuracy criteria when the median specific conductance was less than $25 \mu \mathrm{S} / \mathrm{cm}$. Site operators were much less successful meeting the measurement-accuracy criteria when the median specific conductance was between 30 and $60 \mu \mathrm{S} / \mathrm{cm} ; 38$ to 82 percent of the site operators met the criteria when the median specific conductance of the reference solution was in this range. The Spearman rank correlation coefficient between the median specific conductance of the reference solution and the percentage of site operators achieving the measurement-accuracy criteria was statistically significant for studies 1-24. The large increase in the percentage of site operators that met the measurement-accuracy criteria in studies 11-24 compared with studies 1-10 was mostly because of differences in the median specific conductance of the reference solutions used in studies 1-10 and studies 11-24. The median specific conductance was between 30 and $60 \mu \mathrm{S} / \mathrm{cm}$ in six of the first ten studies; in studies 11-24, the median specific conductance was in this range in only three studies. 
For the 24 studies, a total of 55 percent of the determinations was within $\pm 1 \mu \mathrm{S} / \mathrm{cm}$ of the median values of the individual studies, and 82 percent was within $\pm 3 \mu \mathrm{S} / \mathrm{cm}$ of the median. The percentage of determinations approximating the median values of the individual studies indicates a large degree of measurement precision on an overall basis.

To facilitate the evaluation of $\mathrm{pH}$ and specific-conductance determinations, the current NOS measurement-accuracy criteria need to be revised. In place of the current accuracy criteria of \pm 0.10 or \pm 0.30 unit for $\mathrm{pH}$ and $\pm 4.0 \mu \mathrm{S} / \mathrm{cm}$ for specific conductance, a continuum of accuracy criteria could be established. New measurement-accuracy criteria could, for example, be based on statistical quality-control techniques. Alternatively, adjustable ranges of acceptable percent measurement error depending on the target values of the reference solution could be established.

The operators of a small number of sites accounted for a disproportionately large number of $\mathrm{pH}$ determinations that failed to meet the measurementaccuracy criteria. The operators of 12 percent of the sites that participated in studies 1-24 were responsible for 29 percent of the $\mathrm{pH}$ determinations that failed to meet measurement-accuracy criteria. Ten of the 22 sites whose operators had the poorest success rates of achieving the accuracy criteria for specific-conductance determinations were also among the 32 sites whose operators had the poorest success rates of achieving accuracy criteria for $\mathrm{pH}$ determinations.

\section{SELECTED REFERENCES}

Brooks, M.H., Schroder, L. J., and Willoughby, T.C., 1988, Results of external quality-assurance program for the National Atmospheric Deposition Program and National Trends Network during 1985: U.S. Geological Survey WaterResources Investigations Report 87-4219, $14 \mathrm{p}$.

Chambers J.M., Cleveland, W.S., Kleiner, Beat, Tukey, P.A., 1983, Graphical methods for data analysis: Boston, Duxbury Press, $395 \mathrm{p}$.

Conover, W.J., 1980, Practical Nonparametric Statistics (2d ed.): New York, John Wiley, $493 \mathrm{p}$.

Dixon, W.J. and Massey, F.J., 1969, Introduction to statistical analysis (3d ed.): New York, McGraw-Hill, 638 p.

Galloway, J.N., Cowling, E.B., Gorham, Eville, and McFee, W.W., 1978, A national program for assessing the problem of atmospheric deposition (acid rain): National Atmospheric Deposition Program Report to The Council on Environmental Quality, 94 p.

Hem, J.D., 1985, Study and interpretation of the chemical characteristics of natural water (3d ed.): U.S. Geological Survey Water-Supply Paper 2254, $263 \mathrm{p}$.

Hoaglin, D.C., Moesteller, F., and Tukey, J.W., eds., 1983, Understanding robust statistics and exploratory data analysis: New York, John Wiley, $447 \mathrm{p}$.

Lindberg, S., Bigelow, D., Bowersox, V., Knapp, W., and 01sen, T., 1982, National Atmospheric Deposition Program. annual data summary, precipitation chemistry in the United States: National Atmospheric Deposition Program Subcommittee Number 3, Data Management and Analysis, 134 p. 
Schroder, L.J., and Brennan, J.0., 1984, Precision of the measurement of $\mathrm{pH}$ and specific conductance at National Atmospheric Deposition Program monitoring sites, October 1983-November 1983: U.S. Geological Survey Water-Resources Investigations Report 84-4325, $12 \mathrm{p}$.

Schroder, L.J., and Malo, B.A., 1984, Quality assurance program for wet deposition sampling and chemical analysis for the National Trends Network: APCA/ASQC Specialty Conference on Quality Assurance in Air Pollution Measurements, Boulder, Colo., October, 1984, Proceedings, p. $1-7$.

Schroder, L.J., Brooks, M.H., and Willoughby, T. C., 1987, Results of intercomparison studies for the measurement of $\mathrm{pH}$ and specific conductance at National Atmospheric Deposition Program/National Trends Network monitoring sites, October 1981-October 1985: U.S. Geological Survey WaterResources Investigations Report 86-4363, 22 p.

See, R.B., Schroder, L.J., and Willoughby, T.C., 1988, External qualityassurance results for the National Atmospheric Deposition Program and The National Trends Network During 1986: U.S. Geological Survey WaterResources Investigations Report 88-4007, $15 \mathrm{p}$.

See, R.B., Willoughby, T.C., and Gordon, J.D., 1990, External qualityassurance results for the National Atmospheric Deposition Program/ National Trends Network during 1988: U.S. Geological Survey WaterResources Investigations Report 90-4030, 26 p.

See, R.B., Willoughby, T.C., Gordon, J.D., and Brooks, M.H., 1990, Programs and Analytical Methods for the U.S. Geological Survey Acid Rain Quality Assurance Project: U.S. Geological Survey Water-Resources Investigations Report 90-4029, 57 p.

Taylor, J.K., 1987, Quality Assurance of chemical measurements: Chelsea, Mich., Lewis Publishers, 328 p.

Topol, L.E. and Schwall, R.J., 1987, Network description and measurements for 1981 and 1982, Volume 1: Camarillo, Calif., Environmental Monitoring and Services, Inc., Utility Acid Precipitation Study Program 105, 242 p. 